University of Warwick institutional repository: http://go.warwick.ac.uk/wrap This paper is made available online in accordance with publisher policies. Please scroll down to view the document itself. Please refer to the repository record for this item and our policy information available from the repository home page for further information.

To see the final version of this paper please visit the publisher's website. Access to the published version may require a subscription.

Author(s): Ben Rosamond

Article Title: Disciplinarity and the political economy of transformation: the epistemological politics of globalization studies

Year of publication: 2006

Link to published version: http://dx.doi.org/

10.1080/09692290600769419

Publisher statement: none 


\title{
Disciplinarity and the political economy of transformation: the epistemological politics of globalization studies ${ }^{1}$
}

\author{
Ben Rosamond \\ Department of Politics and International Studies, University of Warwick
}

Zygmunt Bauman (2002) Society Under Siege, Cambridge: Polity Press

Angus Cameron and Ronen Palan (2004) The Imagined Economies of Globalization, London: Sage

Georg Sørensen (2004) The Transformation of the State: Beyond the Myth of Retreat, Basingstoke: Palgrave Macmillan

\section{INTRODUCTION}

In one of the best-regarded books about the subject, Jan Aart Scholte intimates that our established ways of organizing social scientific knowledge are deeply sub-optimal for the effective study of globalization:

\begin{abstract}
Most professional research continues to be funnelled through discipline-related organs. Similarly, most academic conferences have remained tribal conclaves on disciplinary lines. Most academic funding has continued to flow through disciplinary channels, and respect of disciplinarity normally still provides researchers with a faster track to promotion than alternative approaches. In short, some minor inroads aside, disciplinary methodology remains quite firmly entrenched in the contemporary globalizing world (Scholte, 2000: 198).
\end{abstract}

In his review of the same book, James Rosenau (2001) engages in a speculative lament that Scholte's Globalization: a Critical Introduction will only find its way onto reading lists for political science and International Relations courses. The inherent irony alluded to here by Rosenau is that a book which has so much to say about phenomena that are post/supra territorial in character is mediated by a fundamentally territorial epistemological politics. Underwriting this dilemma is a well-worn argument from the sociology of knowledge. Disciplinarity, if is about anything, is about imposing boundaries around the business of knowledge production in modern academe. Academic conversations are, by and large, introverted and self-referential affairs. Members of disciplinary communities are subject to various disciplining norms that socialize them, grant them permissions, 
create incentives for them and impose constraints upon them that together help to define both the academically acceptable and the academically possible in a given field (Klein, 1996).

There are, of course, strong and well-rehearsed defences of the disciplinary status quo that date back at least as far as Durkheim's The Rules of Sociological Method (Durkheim, 1982), which posited a clear rationale for discrete academic communities, each with distinct objects of analysis. Other pro-disciplinary arguments vary from the seductive claim that disciplinarity carries with it a legitimation function that allows scholars to carry on their work without intervention or censure from external authorities to the hard core Kuhnian argument that knowledge cannot progress without being organised by cohesive and closed communities where fundamental assumptions are shared and dissidence is marginalized. .

The appearance of the concept of globalization as a defining motif in the social sciences provokes all manner of thoughts about the limitations of our bounded, territorial academic universe. Different types of argument might be mobilised here. Perhaps the most obvious is that what we label 'globalization' is multidimensional in character (Bernstein, 1991). While most 'common sense' understandings of the term treat it as a phenomenon associated with transformations in the economy, the voluminous literature across many disciplines suggests that we are dealing with a set of processes that inhabit, cut across and affect numerous domains of human action. Disciplines - by definition - deal with bounded domains such as ‘economy’, ‘polity' and ‘society'. They impose boundaries on their respective objects of study and, therefore, arguably contribute to the reification of these objects though their ongoing disciplinary practices (Amin and Palan, 2001: 566). For example, the ongoing practice of economics (the discipline) deals with an assumed object - the economy - that operates as a closed system. The idea of globalization seems to presuppose a transcendence of objective or imagined boundaries in human life because of growing interconnectedness. The point here is not simply that bounded notions of territorial geography lose meaning, but also all bounded action ceases to be explicable in its own terms. It follows that a reconfiguration of academic boundaries is urgent because our extant academic universe is congenitally incapable of dealing with globalization (Smith, 1998). Moreover, as we organize knowledge into bounded domains, so we also presuppose or at least hypothesize the existence of relationships between them, so that - for example - changes in the economy might impact upon the polity. In international studies there is an acute variation of this tendency where the very category 'inter-national' conjures up not only imagery of the shaping actors within that domain (states), but also reifies the boundaries between the international and the domestic. In hard-core versions of 
(neo)realist International Relations, we find perhaps the most aggressive attempt to normalise these images of the ontology of world politics into mainstream disciplinary practice. And yet, if even some of the softer claims about globalization are to be believed, then - for reasons that are well rehearsed - this particular line of academic discourse is phenomenally anachronistic.

So discomfort with disciplinarity is not simply about the failure to embrace Rosenau's entreaty that 'to study globalization, in short, is perforce to undertake interdisciplinary inquiry, so far-reaching and interrelated are its ramifications' (Rosenau, 2001: 115; see also Vickers, 2003). This line of argument runs a little deeper than arguing for the creation of spaces - research institutes, journals, professional associations and so on - that enable productive and enlightening discussion amongst practitioners of various disciplines with an interest in globalization. It is nothing less than an invitation to think about the pathological constraints that disciplinarity imposes upon the development of knowledge about globalization and its consequences. Aside from reifying their objects, runs this line of thinking, disciplines have a habit of reifying themselves to the extent that their internal criteria for the judgement of rigour and excellence became dynamic contributors to their reproduction regardless of whether or how their objects of study are changing. Part of this process, as Arjun Appadurai has argued recently, is a reliance on 'data sets, methodologies, models and techniques' that have built into themselves 'the implicit architecture of the nation-state' (Social Science Research Council, 2003: 26).

There is an immediate and pertinent objection to this line of thinking. The move to eradicate or transcend disciplinarity makes the apparent assumption that the world is globalized or, at the very least, is globalizing. But what if scholars doubt the authenticity of the 'globalization hypothesis'? The issue then becomes one of whether our present disciplinary arrangements allow for effective refutation and critical rebuttal of truth claims that are made around the idea of globalization. Arguments about the need to re-think how we acquire knowledge about or in the context of globalization tend to presuppose a climate of transformation rather than stasis. The assumption of most doubters seems to be that solid, rigorous work using the established tools, axioms and norms of political science, economics and economic history (to name but three fields where such work is especially evident) is capable of showing clearly how claims about globalization - as either a structural condition or a set of effects - amount to mythology or hyperbole. Sociologists of knowledge and disciplinary historians often remind us of how the evolution of (a) forms of academic knowledge and (b) the evolution of modernity are co-constitutive. It follows, therefore, that an incautious rush to formulate a 'global(ization) studies' that presumes a priori that its object 
is globalized may fall into the trap of contributing to the constitution of that globalized reality. Put simply, the very practice of describing a world without borders where power shifts markedly from the public to the private domains, where the authority and autonomy of the state is reduced and where policy possibilities are heavily circumscribed is likely to accelerate the achievement of very reality. This is of particular importance to those scholars of globalization who choose to study this object out of critical motivations and a desire to contribute to the initiation of a more just, equitable, democratic and redistributive world order than presently prevails (Rosow, 2003). It could be argued that the most effective strategy for retaining such possibilities might, paradoxically, be to do in what much of the political science of globalization already does: engage with the common sense understandings of economic or hyper-globalization and produce results that qualify or refute the claims that are routinely made (Rosamond, 2003).

Consequently, those who feel uncomfortable discipline-based discussions of globalization need to find more powerful arguments in favour of overturning epistemological certainties. Each of the books discussed here can be read as representative of one possible reaction to the questions laid out above. But it is worth stressing from the outset that these volumes are written for different purposes and different audiences. Each emerges from a distinctive intellectual location and two of the authors (Bauman and Sørensen) are notable for thinking about what we might call 'epistemological politics' that are internal to disciplines (sociology and political science/IR respectively) rather than offering full-blown inter- or post-disciplinary manifestos as such. The third volume by Cameron and Palan brings together scholars from different disciplinary locations (geography and political science/IR respectively) without explicitly announcing itself as an interdisciplinary project. The product is perhaps more a testament to what might emerge from the types of academic geography and political science each practices.

\section{PUTTING GLOBALIZATION IN ITS PLACE}

The first response, represented by Sørensen's The Transformation of the State, acknowledges that globalization is a multi-faceted and multi-scalar process. As a result, the totality of globalization studies amounts to much more than any single contribution can manage. Isolated studies should make an analytical choice to focus upon a particular aspect of globalization. Thus Sørensen states explicitly that his strategy is to focus on economic globalization (p.25). This is, of course, a choice that positions scholars in a 'best of both worlds' scenario. We are not required to engage in the destructive business of revolutionizing our established (disciplinary) mode of knowledge production. But as Sørensen implies (although never explicitly states) throughout his work, 
disciplines must be open rather than autarchic in their approach to the world. Plus their practitioners must be cognisant of their limitations and the inevitability of only partial explanation. Sørensen’s book is, therefore, nicely positioned to take account of potential transformative changes wrought by globalization, but retains a residual corrective scepticism. This in turn allows for the deployment of standard modes of investigation as correctives to over-zealous assertions about how states are marginalized or residualized by the forces of global capitalism.

One variation of this type of response carries with it rather more wide-ranging implications. Scholte (2000; 2002) observes that much work that purports to be about globalization is actually concerned with other (analytically distinct) things. The ensuing strategy requires the definitional separation of 'globalization' from the likes of 'internationalization', 'liberalization' and 'Americanization' and the subsequent cordoning off of globalization studies to deal with phenomena that are manifestly transcendent of territoriality. Scholte's strategy is countered by those with alternative definitions of globalization (for example Brenner, 1999), but his contribution is not simply about the quest for conceptual precision. Rather Scholte identifies a common intellectual pathology in the social sciences - which he labels 'methodological territorialism' whose practice reinforces a tendency to reify boundaries between distinct spheres, spaces or levels of human action (2002: 27). In other words, territorialist method dominates social scientific norms and induces 'intellectual habits [that] are so engrained that most social researchers reproduce them more or less unconsciously' (2002: 23). We might speculate that territorialist pathologies are themselves a function of disciplinarity. Thus the habits of, say, political science and International Relations become resistant to conceptions of globalization that dissolve well-used heuristic devices which allow scholars to hypothesise relationships between analytically separable scales/levels of human action (see also Rosamond, 2005). This provokes a rather more profound critique of the 'traditionalist' objection raised above. It suggests an in-built tendency to produce results about globalization that are sceptical a priori of any transformationalist claims.

An explanation for this tendency is provided in Stephen Rosow's recent essay on the possibilities for a critical interdisciplinary global studies (Rosow, 2003). Rosow notes that scholars drawn away from the mainstream toward the study of global phenomena regard uncertainty and contingency as defining features of the present and this in turn necessitates a retreat from those characteristics of supposedly 'good' social science (parsimony, objectivity, replicability, the exogenous/epiphenomenal status of language and so on) that lead us to tell stories about an ordered, bounded world. In contrast '[g]lobal studies promotes studies as well as forms of scholarly 
communication rooted in interpretive and critical methodologies that value plurality of methods and rules of enquiry and do not seek a unity of knowledge’ (Rosow, 2003: 5).

This is far beyond the scope of Sørensen's book, but a pertinent question is how such insights, tendencies and intellectual movements are (a) authorized to the extent that they acquire legitimacy in the context of the university and (b) communicated to students, construed as both clients of regimes of knowledge production and potential agents of their reproduction. The question is relevant because of the three books reviewed, Sørensen's is the most explicitly designed for textbook use and a student readership. In this case the clientele is students of International Relations (IR), the discipline, as Rosow notes (2003: 3-6), most obviously authorized to generate valid knowledge about politics beyond the frontiers of the national.

The viability of the state is a major theme in globalization discourse and the status of the state is central to understanding alternative versions of the project of IR. Thus Sørensen's take on the globalization debate is to focus on analytical claims about what economic globalization is doing to the state. In this enterprise, he is far from alone (see, for example, Clark, 1999; Goldmann, 2001; Palan, 2000; Panitch, 1994; Smith, Solinger and Topik, 1999). The Transformation of the State is subtitled 'beyond the myth of retreat' (emphasis added), and part of what Sørensen strives for is the identification of a kind of nuanced analytical 'third way' that is wholly sceptical of two stylised but often heard - hypotheses about the state in the context of economic globalization. Put simply, these are the 'state-centric', 'business as usual' version of statehood that rejects the usual portfolio of claims made on behalf of globalization and the 'retreat' view that tends to be very supportive of the very same assertions. Sørensen articulates his critique with forensic skill and positions himself with wonderful clarity as a proponent of a 'transformationalist' alternative. Here, to put it starkly, the state continues to matter in spite of economic globalization. Yet the way it matters and how it is configured in the context of globalization is changeable and variable across time and space.

But never far from the surface are a series of disciplinary issues. Most obviously, Sørensen writes from a position that is entirely conscious of the ways in which theoretical starting points induce particular types of analytical strategies and thus foreclose the possibility of certain conclusions being reached. He is particularly good at asking awkward yet fundamentally useful questions about the pathologies embedded within the realist and liberal traditions in IR. For example, in his discussions of realism, Sørensen acknowledges that this tradition of enquiry is built around certain stylized axiomatic principles, which - in turn - are designed to facilitate particular kinds of often 
valuable 'what if?' thought experiments about the international system. His point, however, is that realism fails categorically to speak to the debate about the state:

[I]f realists want to make serious contribution (sic) to the debate about what happens to the state, it is necessary to modify some of their core assumptions. If they do not, they will remain painted into a corner where the realist state-centric position is always vindicated, irrespective of what happens in the real world, because the unassailable power of the state is built into the realist assumptions about the world. This reduces the realist state-centric view to a mere matter of faith and the debate with retreat scholars is turned into a 'religious' shouting competition instead of an analytical endeavour to find out what is actually happening (p.181, emphasis added).

To transform itself into this analytical endeavour, Sørensen recommends that realism follows his analysis and relax its core assumptions by both recognizing the multi-actor character of the global polity and unpacking the state from within. Of course, this would do fatal violence to IR realism as an intellectual project. Without its well-rehearsed core assumptions realism, in effect, ceases to be realism. But why make this detour to expose the incapacity of one tradition within IR to engage in a conversation about something that historically it has not been interested in? In so far as there still is an inter-state system, then why not allow realists to carry on regardless with modelling its dynamics and simply broaden the remit of IR to embrace approaches that express an interest in other aspects of world politics? The answer - and Sørensen seems acutely aware of this, even if he does not fully explore its implications - is that IR as a field has been governed by a series of dominant conversations whose introversion prevents scholars from speaking meaningfully to a transformed reality. Moreover, it narrates its own history is terms of a series of debates (between realism and idealism, between traditionalists and behaviouralists and between a realist mainstream and a plurality of alternative voices) that, once retold, help to reinforce the core state-centric, 'hard security’ ontology of the field's (supposedly) legitimate domain (Schmidt, 1998; 2002; Smith, 1995).

From the closing passages of the book, it is clear that Sørensen endorses a social science where there are clear follow-throughs from ‘analysis' to ‘action' (p.193). The persistence of stylized and anachronistic assumptions - and here varieties of liberal IR are equally as culpable as their realist counterpart - is a major block to the achievement of such normative purpose. Engaging in a productive conversation with and about transformed realities is dependent on the practice of 
keeping starting assumptions open (p.7) rather than performing the self-fulfilling axiomatic closures so characteristic of the main schools of IR. Sørensen makes two further arguments, which seem particularly important to his project. First, we are, throughout the volume, reminded of the good examples to IR provided by International Political Economy (IPE) and historical sociology. The clear implication is that the study of states and the states system needs to venture somewhat beyond the safety of its home (IR) domain. Second, Sørensen wants to remind IR of its organic connections to political science and history. By revisiting the classic conundrums of political science and political theory, we are forced to default to a rather more restless analytical position than is commonplace in IR. The most rudimentary questions about democracy - who are the people, how should the people rule, what should be the extent of popular rule? (p. 187) necessitate an engagement with the degree to which the contexts of politics are undergoing alteration. Meanwhile, a reminder that IR's cherished categories - 'the state', 'the states system' and so on - are historicized categories rather than timeless constants actually pulls the carpet from beneath much of what passes for contemporary IR scholarship (pp. 7-14, 189-190).

Sorensen's book is not an exercise in the sociology of knowledge, but his depiction of the orthodox terms of engagement in IR debates about the state is a useful reminder to scholars and a crucial observation for students that the liberal-realist exchange is rooted in conditions of disciplinary foundation (on which see MacLean, 2000; Schmidt, 1998, 2002; Smith, 2004). His conclusion, which he shares with many others, is that the classical IR traditions - realism and liberalism - are 'predestined' to ask inappropriate questions about the contemporary state, thereby underscoring the point that our modes of knowledge production are not straightforwardly responsive to our object. But the argument can be taken much further, and it is by the other two volumes considered here.

\section{REINVENTING SOCIOLOGY}

This all connects to a second argument, that is best expressed by Bauman, not only in the opening passages of Society Under Siege, but also in some of his earlier work (for example, Bauman, 1992). In short, this position claims that the social sciences as we know them are deeply co-constitutive of modernity in the form of the territorial nation-state. The patient in Bauman's diagnostic cubicle is the discipline of sociology, which he describes as 'the intelligence branch of [the sovereign state's] ... practice' (p.2). As noted by Cameron and Palan (p.12), Bauman (1992) draws a link between the ascendancy of the nation-state and the rise of calculative rationality (on the implications for contemporary conceptions of territory see Elden, 2005). The story of twentieth century social science then might be read as an ongoing intellectual project designed to demystify social 
complexity by searching persistently for regularities, routines and predictable patterns. This resonates with the arguments above about social scientific pathologies in that this macro-scholarly project begets not only a methodological orientation that hypothesizes linear causal relationships often between conceptually distinct domains (for example globalization impacts upon national state capacities or changes in the economy induce effects in the polity) - but also a tendency to reify and reproduce particular conceptions of social reality. As Bauman puts it: '[b]ent on cracking the mystery of the "social reality effect", sociologists could not help but discover the sovereign/legitimate power of the state as both its necessary and sufficient condition' (p.6).

The shadow cast by post-Comtian positivism provokes two further observations. First is the relatively simple idea that the founding social context of approaches seeking to reveal 'social statics' is potentially very different from the conditions of today (Smith, 1998: 81). So we might think about the dominant forms of modern social science as path dependent progeny of intellectual choices made in the late nineteenth century in a very different context, albeit a context in which the nation-state form was solidifying as the dominant mode of organizing politics. The second is more central to Bauman's book. This has rather more to do with the relationship between subject and object in sociological enquiry and the presumption of detachment from the object to which 'modern' social science aspires. In a characteristically acute passage, Bauman describes much of contemporary sociology as inhabiting a “'zombie” posthumous phase' and suffering from a condition dubbed 'apoplexia philosophica' (p.37). He argues that the project of analytical detachment needs urgent replacement by a move toward 'grammatical thinking', where the intellectual enterprise is reoriented towards productive conversations with and on behalf of social subjects.

Bauman identifies two ways in which his discipline can (re)acquire importance in the face of the enormous social transformations of our time that much of the book is devoted to describing. In the first place, sociology needs to remember that one of its tasks is to provide a constant reminder that the world is made and unmade by human agency (p.22). Abdication from this task, Bauman insists, will only reinforce the widespread pessimism that attends public discourses of globalisation, where the latter is deemed to be an ineluctable, imperative-setting set of exogenous processes that dramatically impair the possibilities for positive human agency. As he notes in a passage that will resonate with many that have sought to grapple critically with the rhetoric of globalization, 'weakness of agency tends to be self-perpetuating and self-exacerbating and arguably the greatest challenge that confronts sociology at the threshold of the twenty-first century' (p.50). Bauman is 
not alone in drawing such conclusions about the fatality of commonplace discourses of globalisation (see, for example Hay 2002), but he is perhaps more explicit than anyone else in pushing arguments about the complicity of normal social science in embedding such discourses and thereby inducing an atmosphere of pessimistic agency. To this is added sociology's second task: the continuing assertion of human diversity, thereby not only reaffirming the ethical dream of sociology's normative project, but now also cast as a necessary condition for human survival (p.22).

So, we are confronted with a perplexing conundrum. On the one hand sociology is deeply implicated in a form of modernity that not only actively sponsors the casting of social science as a profession of rationalist technicians, but also ruthlessly detaches human beings from engagement with the possibility of their emancipation. On the other, there seems to be no necessary ambivalence about sociology's project. Indeed, within the discipline's DNA resides a code that in fact is essential to overcoming the dehumanizing and negative aspects of globalization. Bauman's largely implied - critique of sociology (even in its emancipatory form) is that it continues to fix its attentions on an object called 'society' (or at least upon a particular conception of society) that is fatally bound up with modernity's ‘sendentary imagination’ (pp. 223-228), where power is associated with territoriality and progressive solutions are fundamentally place-bound. The problem is summed up neatly by Craig Calhoun, also writing about the predicament of sociology:

disciplines are a great deal like nations, not least in their commitment to defending their turf and boundaries, but also in promulgating myths about their essential internal unity and character and literally disciplining the individualistic and dissentient opinions and behaviors of their members (Calhoun, 2002: 2).

Bauman's message, most forthrightly presented in his concluding chapter, seems to be that radical, utopian projects of the past proffered alternatives that sought to solidify the human condition via the application of reason - a central, but specific, accompaniment of place-bound modernity. The surpassing of the state by transnational capital and the dominance of neoliberal discourse has not only rendered power 'placeless', but has also (a) ensured the redundancy of utopian practice and (b) engineered widespread cynicism with the normative category 'society':

This devaluation of territorial engagement and resentment of all finality is manifested in the new mistrust of 'society' and the exasperation caused by all suggestions of society-bound, 
society-promoted and society-managed solutions to jointly or individually experienced human problems (p. 236)

His point is that the practice of using (social scientific) reason to imagine better futures needs to be discontinued in favour of the presentation of alternative presents to ensure engagement with the 'privatized imagination' that is characteristic of 'liquid modernity' (pp. 236-241). The crisis of present sociology is summed up in terms of what Bauman calls a 'double bind': 'it [sociology] lost its natural(ized) object [society] together with its self evident client [the territorial nation-state]' (p.11).

Habitual readers of Bauman will be familiar with this sort of argument (see, for example, Bauman, 1998). His diagnosis of modernity is not unique amongst sociologists and practitioners of allied trades and his extreme depiction of placeless social relations and deterritorialized power renders him vulnerable to some rather obvious critiques from more cautious scholars. Much of Bauman’s book is a sophisticated description of our transformed condition. Globalization is construed as a space of flows that is attended by a new multi-dimensional 'life politics'. This together with novel associated technologies of domination produce the relatively straightforward and familiar argument that actually existing response mechanisms - be they ethical, political, economic - are spatially bounded by the continued compelling structures and narratives of the nation-state. It follows that 'an effective response to globalization can only be global. And the fate of such a global response depends on the emergence and entrenchment of a global (as distinct from 'international', or more to the point interstate) political arena' (p.19). Moreover, while he clearly regards rationalist social science as a co-conspirator in the construction of ordered, place-bounded modernity and (by extension) the consolidation of its structures of power, Bauman's critique of present intellectual projects is rather more centred on their failure to engage appropriately with what the blurb on the back jacket calls the 'profound transformation of social life'. Perhaps this is because they are locked into a rationalist tradition that theorises and explains an order that no longer prevails. In so doing they close off critical and emancipatory possibilities. As indicated above, calls for multi/inter/trans/post-disciplinary social science have often been provoked by observations that the world 'out there' is changing. Bauman might (probably erroneously) be read as falling into this camp, whereas others would want to emphasise the long-standing and rich traditions of nonrationalist scholarship which induces forms of social enquiry that break away from the mainstream's pathological obsession with linearity, order and causality (Amin and Palan, 2001; Jessop and Sum, 2001). 


\section{TELLING STORIES ABOUT GLOBALIZATION}

It is from this non-rationalist starting point that the third argument departs. If nothing else, the incessant background chatter from politicians, policy officials, journalists, corporate actors and various public intellectuals about the ubiquity of globalization has prompted (some) scholars to revisit questions about the quality and utility of extant modes of disciplinary organization. Also under scrutiny are the ontological and epistemological building blocks of those arrangements. A related effect has been the increased attention paid to the significance of that very chatter. The object of enquiry from this starting point is less the idea of globalization as a process or condition with some sort of objective 'out there' quality, but rather the language and discourse of globalization as a shaper of perceptions, assumptions, actions and - perhaps - reality itself. The past few years have seen numerous discussions along these lines, but until now we have lacked a book-length treatment of globalization discourse. It is fortunate indeed that the first cab off the rank is Cameron and Palan's truly outstanding volume. This is not simply the best, sustained discussion of the narrative and subjective qualities of globalization; it is actually amongst the most important books yet written on globalization.

From the outset Cameron and Palan problematize the type of social scientific reasoning that would seek to reveal 'truthful' knowledge about globalization. The inseparability of theory from the world it seeks to describe recasts social scientific endeavour as a form of story-telling. The refutationist wing of globalization studies may have identified the mythological qualities of much rhetoric about globalization, but at the same time it has been remarkably unsuccessful at halting or even qualifying the extensive deployment of claims about globalization amongst policy, journalistic and corporate communities. This is because myths about globalization are not myths about reality; the myths are elemental to that reality (p.7). That they are constitutive of a reality where territoriality is presumed and where the fixed category of 'the state' is threatened in one way or another by the external, 'global' forces is the product of 'considerable social energy' (p.45). Cameron and Palan advance a series of ontological claims about a world of ongoing symbolic transaction. Thus they very carefully examine the ways in which future-oriented pronouncements about globalization emerge from a variety of corporate and policy sources. Urging strategic and programmatic preparation for anticipated futures is a routine pattern within such discourse. As such the (largely unspecified) idea of 'globalization' becomes a powerful framing device in discursively constructing the boundaries of the analytically and normatively possible. 
However, what Cameron and Palan then do - and here they add enormously to the literature on globalization discourse - is to show how these acts of framing are bound up intimately with the social scientific imagination. Indeed, within the academy and within social scientific orthodoxy in particular, we are habitual 'framers' following - as we still tend to - a quasi-Newtonian conception of time and space. The net effect is that academic discussions about globalization habitually mimic the logic of policy discourses in that the boundaries of 'proper' debate are normalized and positions within that debate are clearly delineated. In this way a conventional logic of territorialism is imposed upon academic argument, where 'globalization' occupies a spatial domain that is exogenous to the state. This both facilitates the treatment of globalization as a variable for which measurable proxies must be found and heightens the urgent search for hypothesized causal relationships between globalization and the (nation) state to be investigated. Moreover, social science and conventional historiography invests in a sequential/chronological conception of time, which again is shared with the cadences of policy discourse. Thus, in academic terms, the 'globalization debate' becomes a discussion of how new (at least) transformative processes are undermining the past integrity of the national economy and the contiguity between the nation-state and its traditional economic jurisdiction. With this in mind Sørensen’s book is a prime example of an academic investigation of the veracity of this type of claim. Indeed, Sørensen's interest does not extend to an investigating the plausibility of claims about established national economies (see especially, pp. 26-31). Yet the logic of Cameron and Palan's analysis is to suggest that the 'national economy' of the past is as much a product of ongoing acts of narration as the hypothesized global economy of the present/future, underwritten as it was by forms of social scientific endeavour that simultaneously theorized and endorsed its existence.

There are two obvious implications of the foregoing. The first is the way in which the globalization literature has become entrapped 'within parameters set by our common understanding of what the nation-state has been in the past, is now, and ought to be in the future' (p.54, see also Ruggie, 1998: 172-197). The second implication is the problem that follows from the incapacity of social science to capture 'globalization' via its positivist inclinations that demand layers of analytical separation: '[o]ften, it seems, the globalization debate has become lost in its own rhetoric and, because it does not see rhetoric as constitutive of the "real”, cannot find its way out' (p. 69). Furthermore, there is a recursive and co-constitutive relationship between conventional academic work on globalization and the policy discourses with which much of that research seeks to engage: 'could we have 
thought about globalization or social exclusion, let alone institutionalise them in theory and practice, without the century or so old world of the social sciences?' (p.65).

Armed with a theory of the mechanisms through which the discursive space of globalization and the closely-related derivative idea of 'social exclusion' are constructed, Cameron and Palan devote a good deal of the book to the elaboration of three interacting 'imagined economies' that are the subjects of persistent acts of self-fulfilling narration in the context of globalization discourse: the 'offshore', the 'private' and the 'anti' economies. One of the book's fundamental claims is that the successful imagination of these economic spaces combines to challenge and ultimately unravel established intersubjectivities about social space and political possibilities that follow. Thus the image of 'offshore' - borderless, anarcho-capitalism populated by powerful stateless actors and processes - carries with it a coherent logical story about what should happen within the space still regulated by (national) public authority (an increasingly privatised economy overseen by a 'competition state'). It also helps to rationalise a story about the inevitability of a localized, residual, dependent and marginalized anti-economy, not least because the policy logic of the 'competition state' forces/excuses an abdication of the state from redistributive responsibility. In their relatively downbeat conclusion, which nevertheless is testimony to the power of the processes they theorize, Cameron and Palan at least hint at the task facing a recast 'globalization studies':

Globalization ... relies for its meaning on an acceptance of an image of the world economy operating at different speeds. Since social exclusion is written into this imagery - since it is immanent to the narrative - it becomes difficult to articulate a plausible theory of poverty and poverty reduction without challenging the entire offshore and private economy matrix upon which the discourse of globalization is built (p. 160).

Like Bauman, Cameron and Palan share a commitment to a radical epistemological politics. As should be clear, their book amounts to a full-frontal assault on the metatheoretical assumptions of the social scientific territory into which debates about globalization have been parachuted during the past decade. Their critique of this 'orthodoxy' uses ammunition from numerous fields that, at best, are likely to be found only in the peripheral vision of most scholars of IR and IPE. As they say explicitly (p.43), the intention is to break out of the 'strait-jacket of globalization theory, by drawing on a synthesis of anthropology, historiography, cultural studies, literary criticism and psychoanalysis'. The book's erudition is hugely impressive and its deployment and assimilation of insights from beyond the mainstream is utterly successful in both problematizing and shedding new 
light upon much of the work conducted hitherto on globalization. It is probably fair to characterize the book as a return to the spirit of pre-disciplinary political economy where normative, political and analytical concerns appear to have been inseparable from analytical endeavour and where the migratory movement across the terrain of intellectual life was rather more straightforward than today.

The nagging question is whether it will acquire the readership it so deserves. The book is most obviously addressed to the IPE community in that its depiction of globalization studies orthodoxy is that which deals with questions of state-market-authority dynamics in the context of alleged epochal transformations in the domain of the economy. While some voices in IPE cast the field as open and heterodox (RIPE Editors, 1994) - and thus theoretically amenable to a work like The Imagined Economies of Globalization, other interventions might be read as attempts to formalize the scope of IPE and thereby define not only what it is, but also what it is not (Katzenstein, Keohane and Krasner, 1998). In a poignant echo of their own discussion of imagined economies, so the thrust of Cameron and Palan's work places them in danger of becoming marginalized by the powerful (and still prevalent) narrative logic of disciplinary institutionalization (see Klein 2004).

\section{CONCLUSION}

There are numerous possible reactions to the question of what 'globalization' means for the organization of our knowledge production. Insofar as this issue is discussed, the dominant theme seems to reproduce the notion of globalization as an exogenous pressure that forces us (as academics) to contemplate the appropriate strategic consequences and whether we have the intellectual technologies necessary to engage in the conceptual capture of these processes (Appadurai, 1999; 2000). What have perhaps been missing hitherto are sustained engagements with the obverse question of what our modes of knowledge production mean for the reality of 'globalization'. That we have been collective complicit co-authors of the world we seek to objectify is a clear theme of two of the books discussed here, and all three take very seriously a commitment to academic enquiry as consisting of rather more than the quest to achieve detached, rationalistic and analytical precision. What divides them is disagreement about the degree to which established academic values are able to assist in the crossover from analysis to action, as Sørensen puts it (p. 193). However we chose to conceptualise the linkage between globalization and its exclusionary consequences and if this ultimately bothers us, the task for academics must somehow become altogether more reflexive - about both research and pedagogical strategies - than presently ascendant epistemological norms tend to allow. If our practice is constitutive of the very world 
from which we seek to achieve analytical distance, then it follows that our agency is rather more than we might suppose it to be. What might seem to prevent an exercise of agential muscle in the face of 'globalization' is the powerful institution of disciplinarity, which not only channels academic enquiry in the direction of certain types of investigation that might disallow certain types of reasoning about the world, but which also is locked into conceptions of time and space that turn acts of narrative reproduction into apparently ineluctable structural forces.

What each of these books shows, in quite different ways it has to be said, is that globalization (whether as a theorized structural condition or as an irritating and obdurate empty signifier) does not require us to mount an overt interdisciplinary crusade in order to be engaged with. Bauman and Sørensen illustrate how much can be achieved with a degree of scholarly reflexivity within disciplinary formations. Meanwhile, one important lesson to be derived from reading Cameron and Palan's work is that political economy is - for the most part, and in the UK especially - an open field in which path-breaking work can still be propagated. Disciplinarity has undoubtedly shaped the developing area of globalization studies in a negative sense, but interdisciplinarity will only make a difference if epistemological radical speaks to epistemological radical across the disciplinary divide. A conversation amongst epistemological conservatives will only reproduce the problems that these three books rail against so successfully.

\section{NOTES}

1. Many thanks to Stuart Elden for his extensive and insightful comments on an earlier draft of this article.

\section{REFERENCES}

Amin, A. and Palan, R. (2001) 'Towards a non-rationalist international political economy', Review of International Political Economy 8(4), pp.559-577.

Appadurai, A. (1999) 'Globalization and the Research Imagination', International Social Science Journal 160, pp. 229-238.

Appadurai, A. (2000) 'Grassroots Globalization and the Research Imagination', Public Culture 12(1), pp.1-19.

Bauman, Z. (1992) Intimations of Postmodernity, Cambridge: Polity Press.

Bauman, Z. (1998) Globalization: The Human Consequences, Cambridge: Polity Press. 
Bernstein, R. (1991) The New Constellation: the Ethical-Political Horizons of Modernity/Postmodernity, Cambridge: Polity Press.

Brenner, N. (1999) 'Globalisation as Reterritorialisation: The Re-scaling of Urban Governance in the European Union’, Urban Studies 36(3), pp.431-451.

Calhoun, C. (2002) 'The Future of Sociology: Interdisciplinarity and Internationalization', Paper for the University of Minnesota Department of Sociology Centennial Celebration. March 29-30

Clark, I. (1999) Globalization and International Relations Theory, Oxford: Oxford University Press.

Durkheim, E. (1982) [1895] The Rules of Sociological Method, Basingstoke: Macmillan.

Elden, S. (2005) 'Missing the point: globalization, deterritorialization and the space of the world', Transactions of the Institute of British Geographers (forthcoming)

Goldmann, K. (2001) Transforming the European Nation-State, London: Sage.

Hay, C. (2002) 'Globalisation as a Problem of Political Analysis: Restoring Agency to a Process Without a Subject and Politics to a Logic of Economic Compulsion', Cambridge Review of International Affairs, 15(3), pp. 379-99,

Jessop, B. and Sun, N-L. (2001) 'Perspectives on New Political Economy: Pre-Disciplinary and Post-Disciplinary Perspectives’, New Political Economy 6(1), pp.89-101.

Katzenstein, P.J., Keohane, R.O. and Krasner, S.D. (1998) 'International Organization and the Study of World Politics’, International Organization 52(4), pp. 645-685.

Klein, J.T. (1996) Crossing Boundaries: Knowledge, Disciplinarities and Interdisciplinarities, Charlottesville, VA: University of Virginia Press.

Klein, J.T. (2004) 'Disciplinary Origins and Differences', Fenner Conference on the Environment, Australian Academy of Science, Canberra, 24-25 May, http://www.science.org.au/proceedings/fener/klein.htm

MacLean, J. (2000) 'Philosophical Roots of Globalization and Philosophical Routes to Globalization', in Germain, R. (ed.) Globalization and its Critics: Perspectives from Political Economy, Basingstoke: Macmillan, pp. 3-66.

Palan, R. (2000) 'Recasting Political Authority: Globalization and the State', in Germain, R. (ed.) Globalization and its Critics: Perspectives from Political Economy, Basingstoke: Macmillan, pp.139-163.

Panitch, L. (1994) 'Globalization and the State', in Miliband, R. and Panitch, L. (eds) The Socialist Register 1994: Between Globalism and Nationalism, London: Merlin Press, pp. 60-93.

RIPE Editors (1994) 'Editorial: forum for heterodox political economy', Review of International Political Economy 1(1), pp. 1-12. 
Rosamond, B. (2003) 'Babylon and On: Globalization and International Political Economy', Review of International Political Economy 10(4), pp. 661-671.

Rosamond, B. (2005) 'Globalization, the ambivalence of European integration and the possibilities for a post-disciplinary EU studies', Innovation: the European Journal of Social Science Research 18 (forthcoming)

Rosenau, J. N (2001) 'Supraterritoriality and Interdisciplinarity', International Studies Review 3(1), pp. 115-118.

Rosow, S.J. (2003) 'Toward an Anti-Disciplinary Global Studies', International Studies Perspectives 4(1), pp.1-14.

Ruggie, J.G. (1998) Constructing the World Polity: Essays on International Institutionalization, London: Routledge.

Schmidt, B.C. (1998) The Political Discourse of Anarchy: A Disciplinary History of International Relations, Albany, NY: State University of New York Press.

Schmidt, B.C. (2002) 'On the History and Historiography of International Relations', in Carlsnaes, W., Risse, T. and Simmons, B. (eds) Handbook of International Relations, London: Sage, pp. 3-22.

Scholte, J.A. (2000) Globalization: a Critical Introduction, Basingstoke and New York: Palgrave Macmillan.

Scholte, J.A. (2002) 'What is Globalisation? The Definitional Issue - Again', CSGR Working Paper No. 109/02, University of Warwick. http://www.warwick.ac.uk/fac/soc/CSGR/wpapers/wp10902.pdf

Smith, D.A., Solinger, D.J. and Topik, S.C (eds) (1999) States and Sovereignty in the Global Economy, London and New York: Routledge.

Smith, M.J. (1998) Social Science in Question, London: Sage.

Smith, S. (1995) 'The Self-Images of a Discipline: A Genealogy of International Relations Theory', in Booth, K. and Smith, S. (eds) International Relations Theory Today, Cambridge: Polity Press, pp. 1-37.

Smith, S. (2004) 'Singing Our World Into Existence: International Relations Theory and September 11’, International Studies Quarterly 48(3), pp. 499-515.

Social Science Research Council (2003) 'I \& I Interviews Arjun Appadurai', Items \& Issues 4(4), pp. 24-27.

Vickers, J. (2003) 'Diversity, Globalization and “Growing Up Digital”: Navigating Interdisciplinarity in the Twenty-First Century’, History of Intellectual Culture 3(1), pp. 1-19. 